\title{
Growth Layers in Tooth Cement and Dentine of European Bison and its Hybrids with Domestic Cattle
}

\author{
Galina A. KLEVEZAL \& Zdzisław PUCEK
}

\begin{abstract}
Klevezal G. A. \& Pucek Z., 1987: Growth layers in tooth cement and dentine of European bison and its hybrids with domestic cattle. Acta theriol., 32, 9: 115-128 [With 2 Tables, 3 Figs. \& Plates V-VI]

For checking the possibility of age determination from histological structure of teeth, the structure of cement and dentine of incisors was studied in European bisons, Bison bonasus, $(\mathrm{n}=29)$ and hybrids of bison with cattle $(n=9)$ and cattle $(n=3)$. The number of cement layers was related to the known age of the animals. It was found that the number of primary incremental lines in the cement on the lingual surface of the incisor agreed with the age of the tooth. The formation of layers on the labial surface of the teeth older than 7 years progresses irregularly. The readability of cement layers in bison is poor, in hybrids it is slightly better, and in cattle it is good. Due to this, counting of layers by independent investigators gives a low agreement of estimates (in bisons and hybrids about $30 \%$ ). Repeated counting produced an agreement between the number of incremental lines and age. Thus for an estimation of the number of cement layers a proper part of a tooth should be chosen and some experience must be gained. Layers of secondary dentine were well visible in the part adjacent to pulp cavity, but its line at the site of meeting of the primary dentine is not distinct. This makes impossible estimation of age of the studied animals by th s method. No relationship was noted between the structure of cement layers and environment where the animals were living (closed reserves, forest), pregnancy and lactation. The pattern of the first incremental line enable the estimation of animal birth season.

IN. K. Koltzoff Institute of Developmental Biology, USSR Acad. Sci., 26 Vavilov Str., 117334 Moscow, USSP, and Mammals Research Institute, Polish Acad. Sci., 17-230 Białowieża, Poland]
\end{abstract}

\section{INTRODUCTION}

An exact technique for determination of age of the European bison, Bison bonasus (Linnaeus, 1758), has not yet been evolved. There was no need for this since for many decades this species has been living exclusively in zoological gardens or reserves, and the absolute age of the animals was known. However, this need arose after the restitution of the species in free-ranging herds. Only in recent years the eruption and renlacement of teeth and complete formation of their crowns were studied, and investiøations on age-related attrition of teeth are planned (Węgrzyn \& Serwatka, 1984). 
In a closely related American bison, Bison bison (Linnaeus, 1758) tocth eruption and wear in relation to age were studied by Fuller (1959) and Frison and Reher (1970). Novakowski (1965) and Haynes (1984) estimated the age of these animals also on the basis of the annual growth of tooth cement layers. These authors used a technique of ground sections of Pm4 and M1 etched in formic acid. However, since they were not studying animals of known age, they could not verify the accuracy of their age determinations.

The purpose of this study was the histological analysis of growth layers in tooth cement and dentine of European bison and its crosses with domestic cattle, and assessment of the possibility of using these structures for the determination of age in these animals.

\section{MATERIAL AND METHOD}

For the study the first incisors I1 (exceptionally I3 or C - see Table 1) were used, obtained from 19 bisons from the Polish reserves and 10 bisons from a free-ranging herd in the Białowieża Forest. The dates of birth and death of the animals living in reserves were known, but in the case of the animals from the free-ranging herd only the death date was known. Their age was estimated approximately by Dr. Z Krasinski, the experienced scientific officer of the National Park in Białowieża, on the basis of the features of teeth, exterior and knowledge of herd structure. Additionally in the study the incisors were used of 9 hybrids of European bison with cattle, obtained from animals of known age, of the first generation (F1) and back-crosses - B1, B2 with genetic participation of bison of $25 \%$ and $12.5 \%$ respectively. The hybrids were living always in large (10 hectares) enclosures in the forest in one of the reserve of the Białowieża Forest. Moreover, the incisors were investigated of three cattle: one bull of known age and two adult cows of unknown age.

The material was obtained from the collection of the Mammals Research Institute, PAS in Białowieża, and from the Department of Animal Anatomy, Warsaw Agricultural University (8 bison).

The teeth were decalcified in 5\% nitric acid for 4-6 days and washed then during one day in running water. Transverse sections through the centre of the tooth and longitudinal sections in sagittal plane of the root, 20-30 microns thick, were obtained using a freezing microtome and stained with Ehrlich's hematoxylin. Cement and dentine layers were counted several times at monthly intervals between each counting without considering the age of the animals. The readability of the layers was scored using a five-degree scale taking into account the reproducibility of the estimates of their counts (see Klevezal et al., 1981).

\section{RESULTS}

\subsection{Layered Structure of Cement}

In European bison as well as in hybrids the total thickness of cement on the lingual side of the tooth was greater than on the labial side. Narrow, dark-staining incremental lines divided the cement into layers. 
The lines were wavy, differing in contrast. Frequently several faint lines merged to form on very distinct (Photos 1-3, Plate V). More distinct or primary lines and faint accessory lines could be discerned. In the cement on the labial side of the teeth these accessory lines were less numerous than on the lingual side.

In the sections of certain teeth the whole cement stained weakly although dentine took up the stain normally. The external layers of cement were usually damaged in these teeth. These defects were most pronounced in these teeth whose surface was most intensively blanched. (It seems that this was an effect of skull blanching by perhydrol).

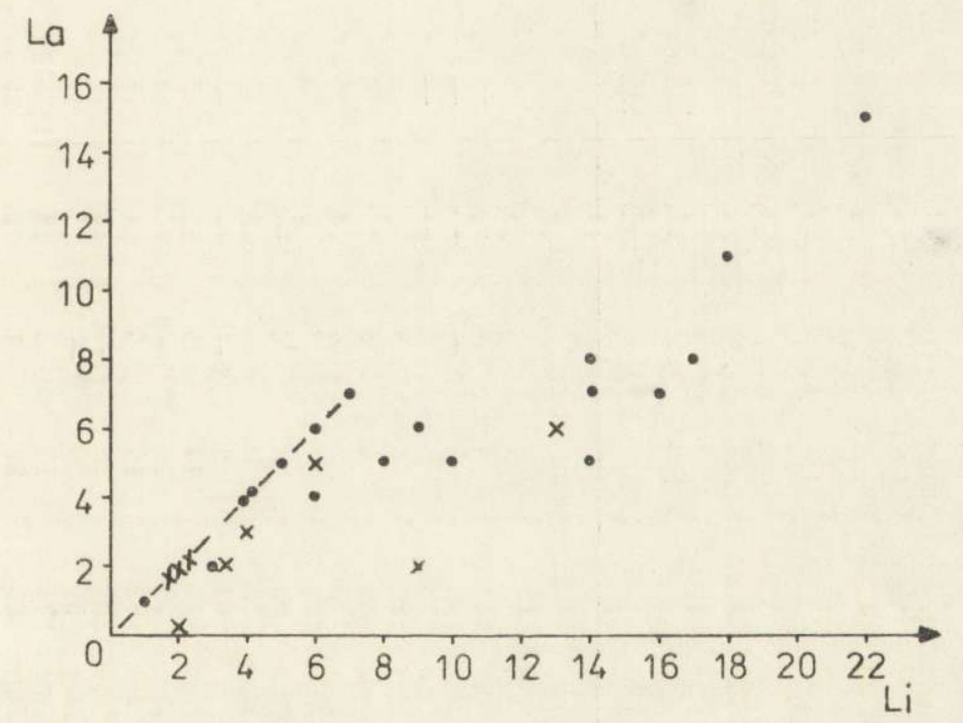

Fig. 1. Correlation between the number of primary incremental lines on lingual (Li) and labial ( $\mathrm{La})$ sides of incisors in European bison ( and its hybrids with the domestic cattle (x). Dashed line joins points with the 1:1 ratio.

In European bison from reserves and in hybrids the primary lines in cement were counted in the first incisor (I1) on the lingual and labial sides, and all lines (primary and accessory) were counted on the lingual side. The number of lines was compared with the age of tooth, which was - in the case of I1 - two years lower in relation to the age of an animal (N. B. in the case of I3 and C it was lower by 3 and 3.5 years respectively; according to Węgrzyn and Serwatka (1984) first permanent incisors are replaced at the age of 22-26 months, third incisors at 35-40 months, and canines at 38-44 months).

Table 1 shows that the age of a tooth corresponds in the greatest 


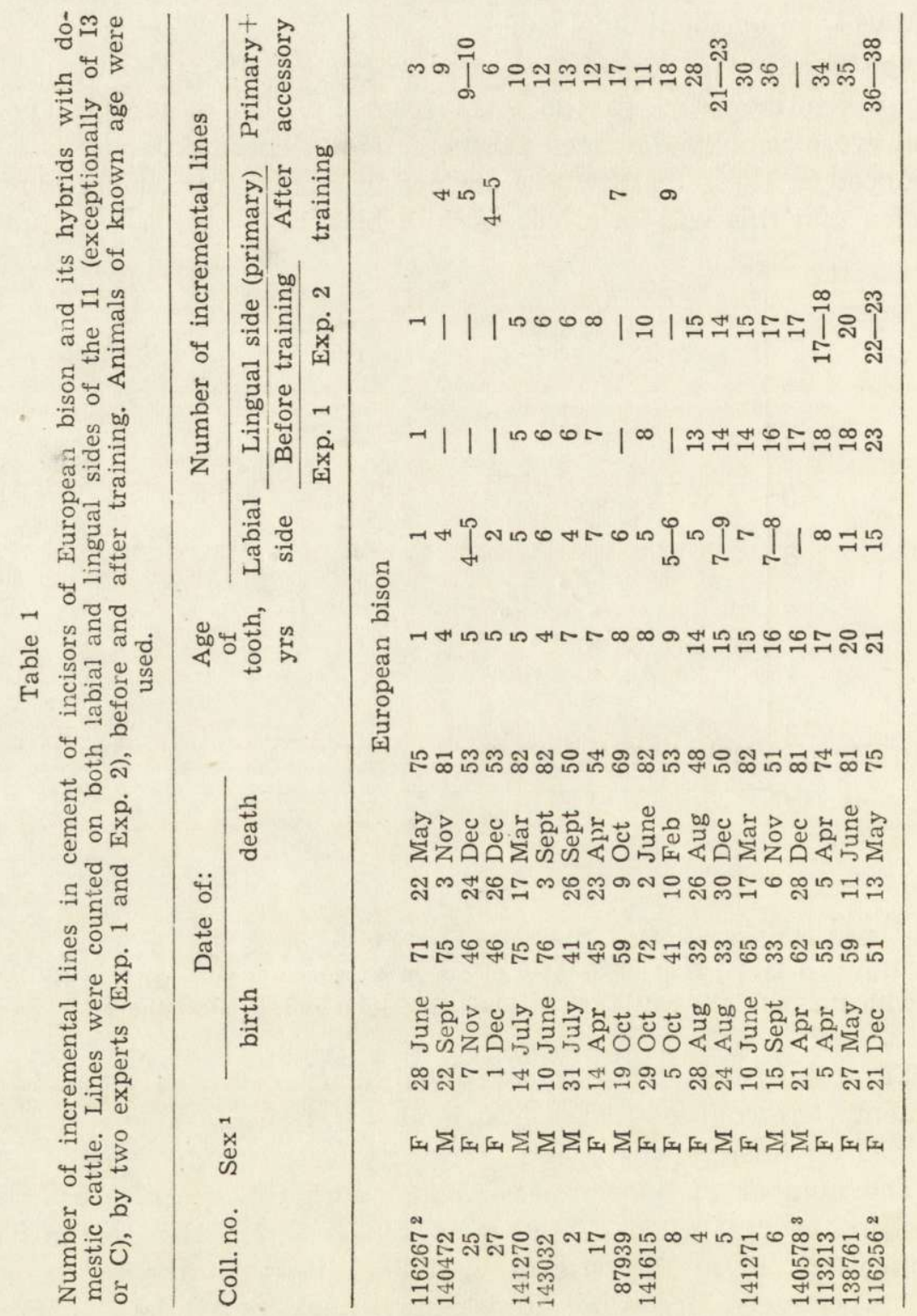




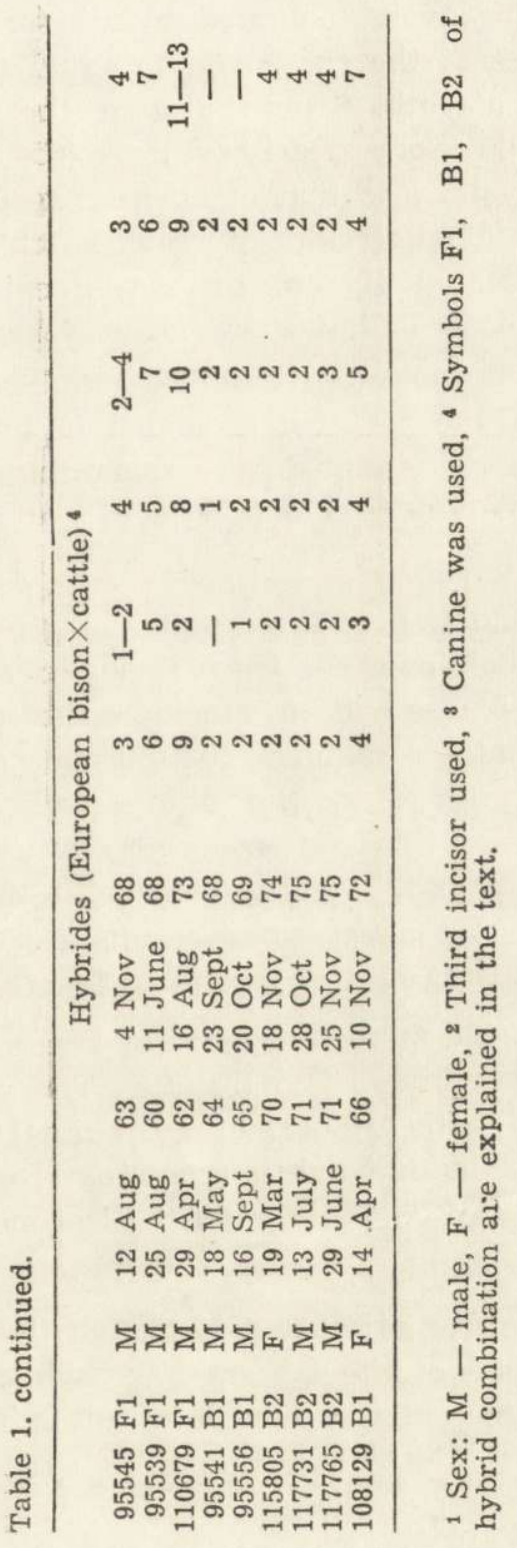


degree to the number of primary lines in cement on the lingual side. Probably one primary line is deposited there annually. In cement on the labial side the number of primary lines in animals aged up to 9 years was either equal to or lower than the age of a tooth in years, while in the older animals it was always lower (Table 1). The ratio of the number of cement layers, bounded by the primary lines, on the lingual and labial sides of the root may be equal (1:1) during the first 7 years of the life of a tooth. After that time the formation of cement layers on the labial side progresses irregularly (Fig. 1). The ratio of the number of the primary lines to that of all lines (primary and accessory) in the cement on the lingual side approaches $1: 2$ (the mean value is 1:1.9). This means that annually one primary line is formed beside one accessory line. This process is, however, not very regular (Table 1).

Blind counts have demonstrated that the number of lines in cement on the lingual side of the root corresponded in half the cases to the number of years of an individual, in the remaining cases the error was in the range of \pm 1 year, and in only two out of 19 cases it was \pm 2 years (Table 1).

One month after calculation of the number of growth layers the teeth preparations of bison of known age were reviewed again. Knowing then the age of the animals it was tried to elucidate the cause of the previous erroneous estimates, and to establish the number of annual layers in cement. Immediately after that, the number of cement layers was counted in hybrids without taking into consideration their age. In all cases the number of cement layers agreed with the age of the teeth (Table 1). This shows that satisfactory results can he obtained owing to preceding training in the counting of annual layers.

In free-ranging bison the number of cement layers was counted twice, vesfore and after the above described training. The result of the second counting was compared with the age of the animal estimated approximately on the vasis of teeth condition and external appearance. The obtained results were usually arreeing, but the last method overestimated the age of older animals (Table 2).

In counting of the number of cement layers on the lingual side attention was paid to the part of the annual layer which was in the stage of formation, that is on the external margin. In all animals dying between October and February this margin contained a dark stained line while in the animals dying in the remaining seasons of the year this site contained either a dark line or a bright band (Fig. 2):

In cattle growth layers were very distinct. In the animal aged 5 years and 1 month three layers were found. In cattle the first incisors are 
replaced at the age of $20-26$ months (Habermahl, 1975). It may be assumed that these were the annual lines. In other animals the accessory lines were also present.

Table 2

Results of age determination in free-ranging European bison. Twofold countings of incremental lines in cement before (1) and after (2) training are presented. First incisor was used in all cases but no. 113485, in which canine was available.

\begin{tabular}{|c|c|c|c|c|c|c|c|c|}
\hline \multirow{2}{*}{ Coll. no. } & \multirow{2}{*}{ Sex } & \multirow{2}{*}{\multicolumn{3}{|c|}{$\begin{array}{c}\text { Date of } \\
\text { death }\end{array}$}} & \multicolumn{2}{|c|}{ No. of incremental lines } & \multicolumn{2}{|c|}{ Age, yrs } \\
\hline & & & & & 1 st count & 2nd count & Cement & Est. \\
\hline 113485 & M & 11 & July & 74 & 10 & $8-9$ & $10-11$ & 15 \\
\hline 116028 & $\mathrm{~F}$ & & Jan & 75 & 24 & $18-20$ & $20-22$ & 18 \\
\hline 116162 & M & & Apr & 75 & $13-14$ & 11 & 13 & 15 \\
\hline 140473 & M & 3 & Nov & 81 & 10 & 8 & 10 & 12 \\
\hline 140576 & M & 8 & Dec & 81 & 12 & 10 & 12 & 13 \\
\hline 141218 & M & 18 & Feb & 82 & $8-9$ & $9-10$ & $11-12$ & 11 \\
\hline 141613 & M & 1 & June & 82 & 13 & 10 & 12 & 15 \\
\hline 142035 & $\mathrm{~F}$ & 20 & Aug & 82 & 15 & 16 & 18 & 19 \\
\hline 144405 & $\mathrm{~F}$ & 26 & Jan & 83 & 5 & 4 & 6 & 6 \\
\hline 149821 & $\mathrm{~F}$ & & June & 84 & 13 & 11 & 13 & $12-13$ \\
\hline
\end{tabular}
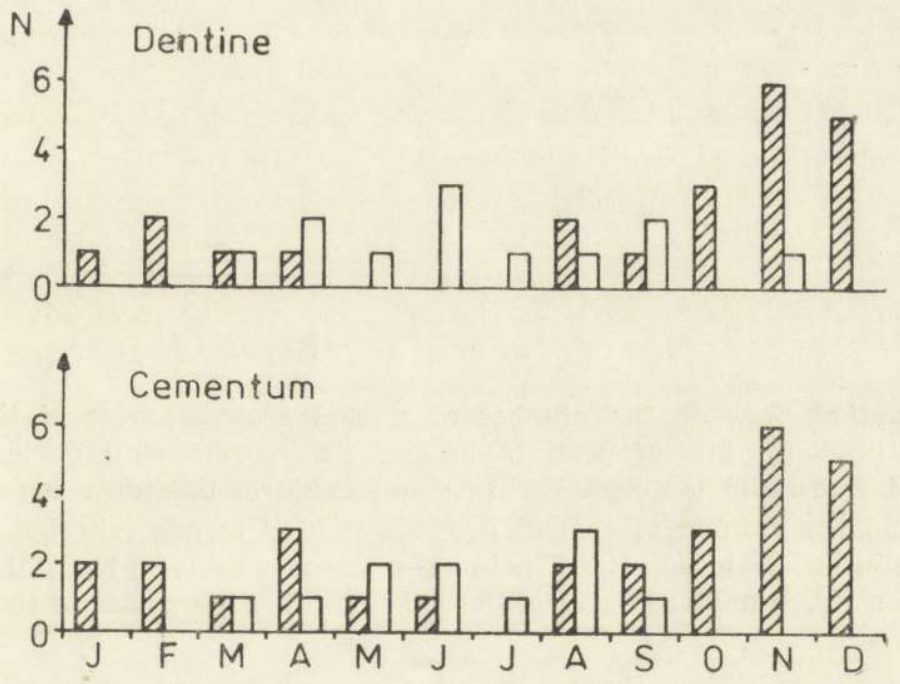

Fig. 2. Time of formation of the dark (shaded bars) and light (open bars) parts of the annual layers in dentine and cement of incisors in European bison and its. hybrids with domestic cattle. $\mathrm{N}$ indicates the number of individuals. 


\subsection{Layered Structure of Dentine}

Layers composed of dark and bright staining bands were well discernible on transverse sections of the teeth of European bison, hybrids and cattle. Width of the layers decreased towards the centre of tooti and their readability increased. The borderline of secondary dentine was poorly visible (Phot. 4, Plate VI). The readability of growth layers varied in different animals, and that was the cause that their number could have been established in only 21 out of 29 bison, in 8 out of 3

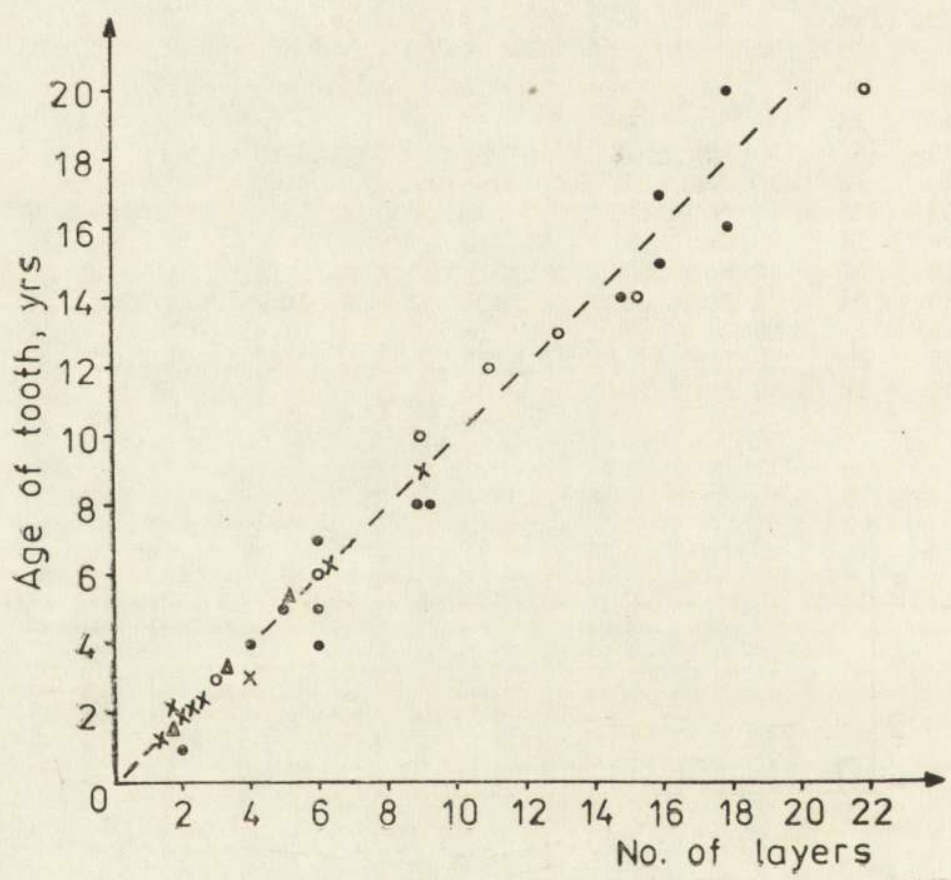

Fig. 3. Correlation between the number of annual growth layers of the dentine and age of the tooth in European bison and its hybrids with domestic cattle. In a series of free-ranging European bison and cattle of unknown age (used here for comparison) the number of cement layers was used as age criterion. Circles free-ranging European bison, filled points - European bison from the reserve, crosses - hybrides, triangles - cattle. Dashed line joins the points of the 1:1 ratio.

hybrids, and in all 3 cattle. A comparison of the number of dentine layers with the age of a tooth (Fig. 3) shows that they were mostly annual layers. However, in all studied animal groups cases were encountered of disagreement between the number of dentine layers and age.

In the animals dying in May or June bright dentine layers were 
present, and in those dying between October and February dark bands were found (with the exception of one animal). In the remaining months in the walls of pulp cavity both dark and bright dentine bands were seen (Fig. 2).

\subsection{Annual Layers in Animals from Various Groups}

The evaluation of cement layer readability in the five-degree scoring gave the following characteristic of animals studied: bison from the free-ranging herd $-2-3$, bison from the reserves -3 , bison $\times$ cattle hybria's - 3-4, cattle -4 . Two independent assessments of the number of cement layers in 10 free-ranging bison were different in all animals (Table 2). In bison from reserves and hybrids an agreement of two assessments was observed in only $30 \%$ of animals (Table 1 ). In two (out of three) cattle the count of cement layers in the incisors showed a good agreement.

The number of dentine layers and the age of the tooth (or the number of cement layers, in case of absence of data about the age) were compared. A tendency was observed for greater deviation from the equal ratio in European bison in relation to hybrids and cattle (Fig. 3).

Three bison (Coll. nos: 87939, 113213, 116256) were living initially in the reserve, and then were released in freedom. In these animals no differences were found in the pattern of dentine and cement layers formed during the life in the reserve and in the forest.

The structure was compared of the annual cement and dentine layers in female bison and hybrids from the reserve in the years when they had calves and in those in which they gave no birth. No changes in the structure of dentine and cement were demonstrated which could be related to pregnancy, parturition or lactation.

\subsection{Relationship to Birth Season}

The relationship was sought for between the structure of growth layers in cement and the season of birth. The studied bison and hybrids were born between March and October. The width of the first cement layer varied in a wide range in various animals, but no relationship of this feature to birth time was noted.

The dark incremental line, bounding the first annual cement layer, only in some animals reached the end of the dental root, more frequently it approached the dentine borderline or disappeared at some distance from the end of the root. This distance was measured in sections passing precisely across the centre of the pulp cavity of I1. It was found that 
in the animals born in autumn and winter this distance was, on the average, nearly five times longer than in those born in spring and summer (Phot. 5-6, Plate VI).

\section{DISCUSSION}

Raports have accumulated on cases in which an insufficient readability of growth layers made impossible a precise determination of the animal age, e.g. in the Alaskan moose, Alces alces, of known age from 2 to 11 years the number of cement layers in I1 agreed with the age of the animals in $56 \%$ of cases (Gasaway et al., 1978). Similarly in the musk ox, Ovibos moschatus, in five independent cement layer counting in 16 animals significant differences were found indicating the unsuitability of this method for age determination (Gronquist \& Dinneford, 1984). In European bison cement layers were also indistinct, but our observations suggested that it was very important in this analysis to select the proper part of a tooth, and to gain some experience in the counting of annual layers. It was found in European bison, that only the number of growth layers on lingual side of the incisor root indicate the age of an individual. In the analysis of the group of hybrids of known age we demonstrated also that experience in the determination of the number of layers reduced the error of age determinations.

The primary lines in cement of the lingual side of permanent I1 in bisun gave a greater contrast than the accessory lines, even when they are fusing. These lines are formed, probably, each year, with the first line appearing in animals three years old. Due to this, the estimated age of an animal will be equal to the number of primary lines plus two. The probable error may be \pm 1 year.

In certain ungulates secondary dentine has distinct layers. If the age is known, at which the first layer is formed, then the age of the animal may be determined on the basis of this information (cf. e.g. Haagenrud, 1978). In the bison secondary dentine layers, probably annual, are discernible. However, primary dentine layers are indistinct and the borderline between primary and secondary dentine is not evident. Thus it was not possible to establish at what age of an animal the first layer of secondary dentine is formed. However, the age of a tooth should not be lower than the number of well-visible layers of secondary dentine. Thus counting of dentine layers may be helpful, to some extent, when determination of age is based on cement layers.

The knowledge of the time at which various parts of the annual growth layer are formed is important both for age determination and for the estimation of death time. It seemed previously that the primary lines in the cement as well as the narrow dark lines in dentine are formed during winter (Klevezal \& Kleinenberg, 1967). A more detailed analysis 
of the period of formation of various parts in the annual layers in many mammal species has led to the conclusion that the primary incremental lines in cement may develop in various seasons of the year in different mammals, even if they are living in the same territory (Grue \& Jensen, 1979). Data obtained for European bison and their hybrids with cattle show that dark lines form in cement and dark bands in dentine in late autumn and winter. This process is, probably, highly variable individually, since in spring as well as in autumn animals were found forming either the translucent or the opaque part of the annual layer of dentine or cement (cf. Fig. 2).

No differences were demonstrated in the pattern of dentine and cement growth layers between free-ranging bison, bison and hybrids living in reserves and cattle, although the readability of these layers was slightly increasing in this sequence of animal groups. This observation was unexpected, since one might expect that in domestic animals the annual layers would be less readable than in wild ones. The observed slight differences in the readability of the layers might have been also a result of age differences between these groups. Hybrids and cattle were usually younger ( $4-7$ years) than bisons ( $10-20$ years), and it is known that in young animals the layers are less wavy and can be counted more easily.

In our rather small material the possibility was found of using the pattern of the first annual cement layer far the determination of birth time of the animal. The first permanent incisors in bison and cattle erupt usually two years after birth. This occurs, probably, in spring in the animals born in spring, and in autumn in those born in autumn. In most mammals the growth rate progresses more slowly in autumn than in spring and summer. Thus, a tooth erupted in spring can form its root before the autumn-winter season, when the first cement line is formed and reaches the tip of the root. In the teeth erupted in autumn the growth of the root would not be completed till the time of formation of the first cement line, and it would be continued in the next spring. Because of that, the first cement line in that case is not reaching the tip of the incisor root. The obtained results seems to confirm this. This method of estimation of animal birth time cannot be precise because of individual variability in the time of eruption of the permanent incisors (cf. Węgrzyn \& Serwatka, 1984) but it may be useful, for example, in ecological studies.

Acknowledgements. Thanks are due to N. V. Peremyslova for technical assistance, This work is the results of bilateral cooperation between the N. K. Koltzoff Institute of Develormental Biology of the USSR Academy of Sciences and the Mammals Research Institute of the Polish Academy of Sciences under the programme No 25.1(2). 


\section{REFERENCES}

1. Frison G. \& Reher C., 1970: Age determination of buffalo by teeth eruption and wear. [In: "The Glenrock buffalo jump", G. Frison, ed.]. Plains Anthropol. Mem., 7: 46-59.

2. Fuller W., 1959: The horns and teeth as indicators of age in bison. J. Wildl. Manage., 23: 342-344.

3. Gasaway W. C., Harkness D. B. \& Rausch R. A., 1987: Accuracy of moose age determinations from incisor cementum layers. J. Wildl. Manage., 42: 558-563.

4. Gronquist R. M., \& Dinneford W. B., 1984: Age determination of muskoxen from dental cementum annuli. Biol. Pap. Univ. Alaska, Spec. Rep. nr 4: 67-68.

5. Grue H. \& Jensen B., 1979: Review of the formation of incremental lines in tooth cementum of terrestrial mammals. Danish Rev. Game Biol., 11, 3: $1-48$.

6. Haagenrud H., 1978: Layers in secondary dentine of incisars as age criteria in moose (Alces alces). J. Mammal., 59: 857-858.

7. Habermehl K-H., 1975: Die Alterbestimmung bei Haus- und Labortieren. Verlag Paul Parey, Berlin, Hamburg: 1-216.

8. Haynes G., 1984: Tooth wear rate in northern bison. J. Mammal., 65: 487-491.

9. Klevezal G. A., Grue H. \& Mina M. V., 1981: A method of readability evaluation of recording structures in age determination of animals. Zool. Z., 60: 1869-1877. [In Russian with Engl. summ.].

10. Klevezal G. A. \& Kleinenberg S. E., 1967: Age determination of mammals from annual layers in teeth and bones. Israel Programm for Scientific Translations. Jerusalem 1969: 1-128.

11. Novakowski N. S., 1965: Cemental deposition as an age criterion in bison, and the relation of incisor wear, eye-lens weight and dressed bison carcass weight to age. Canad. J. Zool., 43: 173-178.

12. Węrryn M. \& Serwatka S., 1984: Teeth eruption in the European bison. Acta theriol., 29: 111-121.

Received, September 20, 1986. Accepted, December 10, 1986.

Galina A. KLEVEZAL i Zdzisław PUCEK

WZROSTOWE SŁOJE W CEMENCIE I DENTYNIE ZĘBOW ŻUBRA I ŻUBRONI

\section{Streszczenie}

W celu sprawdzenia możliwości określenia wieku żubrów, Bison bonasus (Linnaeus, 1758) i ich mieszańców z bydłem, na podstawie budowy histologicznej zzębów, przeprowadzono badania struktury cementu i dentyny siekaczy 29 żubrów, 9 żubroni i 3 sztuk bydła. Wiek wiẹkszości badanych zwierząt był znany, co umożlliwiało weryfikację uzyskiwanych ocen. Wyrazistość słojów cementu u żubrów jest na og ́́ł slaba, nieco lepsza u żubroni, dob a u bydła (Fot. 1-3, Tabl ca V). W wyniku tego niezależne liczenia słojów przez różne osoby dają małą zgodność ocıen (u żubrów i hyb ydów - ok. 30\% - Tabela 1). Liczba ciemno barwiących się linii podstawowych $\mathrm{w}$ słojach rocznych cementu po lingualnej stronie korzemia 
siekacza zgodna jest $\mathrm{z}$ wiekiem zęba (Tabela 1). Tworzenie się słojów po stronie labialnej w zębach starszych niż 7 lat postępuje nieregularnie (Tabela 1, Ryc. 1). Zgodność liczby linii podstawowych $\mathrm{w}$ cemencie $\mathrm{z}$ wiekiem zęba uzyskiwano w powtórnych ich liczeniach (Tabela 1). Dla właściwej oceny liczby słojów cementu należy przeto wybrać odpowiednią część zęba i nabrać pewnej wprawy w ich liczeniu.

Słoje wtórnej dentyny (Fot. 4, Tablica VI) były dobrze widoczne w części przylegającej do kanału zęba lecz jej granica $z$ dentyną pierwotną jest niewyraźna. Uniemożliwia to policzenie słojów dentyny wtórnej a zatem i dokładną ocenę wieku.

Nie stwierdzono zależności między budową słojów cementu a środowiskiem bytowania badanych zwierząt (rezerwaty, las), ciążą, porodami i laktacją. Sezon urodzenia zwierzęcia można określić na podstawie odległości pierwszej ciemnej linii podstawowej cementu od końca korzenia siekacza (Fot. 5-6, Tablica VI). 
Photo 1-3. Primary (p) and accessory (a) incremental lines in tooth cement seen on longitudinal sections of incisors. $\mathrm{Li}$ - lingual side, $\mathrm{La}$ - labial side.

Photo 1. I1 of the European bison form the reserve, male, coll. no. 141270.

Photo 2. I1 of the hybride female (25\% European bison), coll. no. 108129.

Photo 3. I3 of the European bison from the reserve, female, coll. no 116256 .

\section{Plate VI}

Photo 4. Transverse section of I1 of the hybrid male $(50 \%$ of European bison), coll. no. 110679. Layered structure of primary (a) and secondary (b) dentine is seen.

Photo 5-6. Comparison of distance between the end of the I1 root and the first primary incremental line in tooth cement of animals born in different seasons.

Photo 5. Hybrid of European bison and domestic cattle (12.5\% bison), male, born in June, coll. no. 117675.

Photo 6. European bison, female born in November, coll. no. 25. 


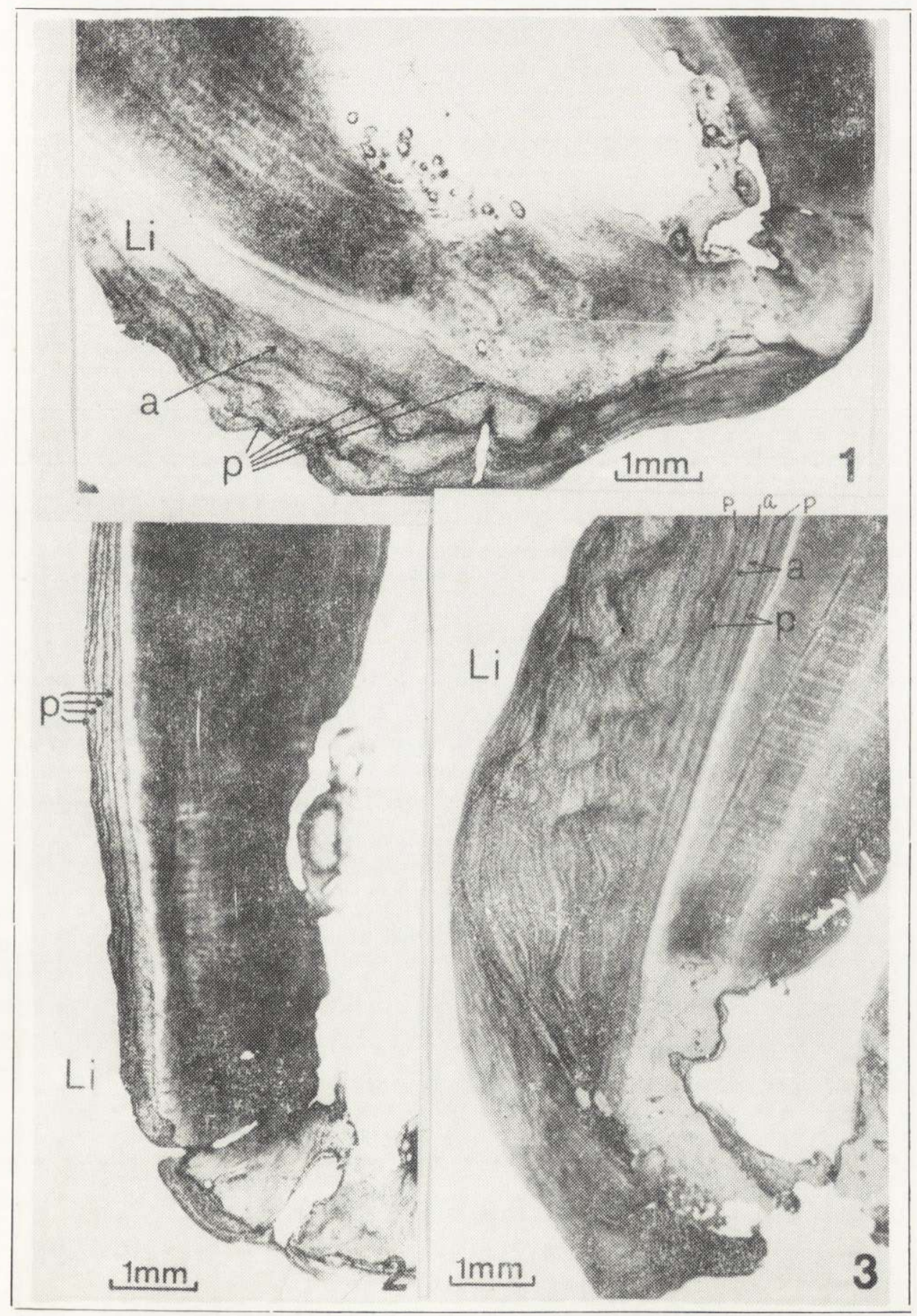

G. A. Klevezal \& Z. Pucek auctores phot. 
ACTA THERIOLOGICA, Vol. XXXII, 9

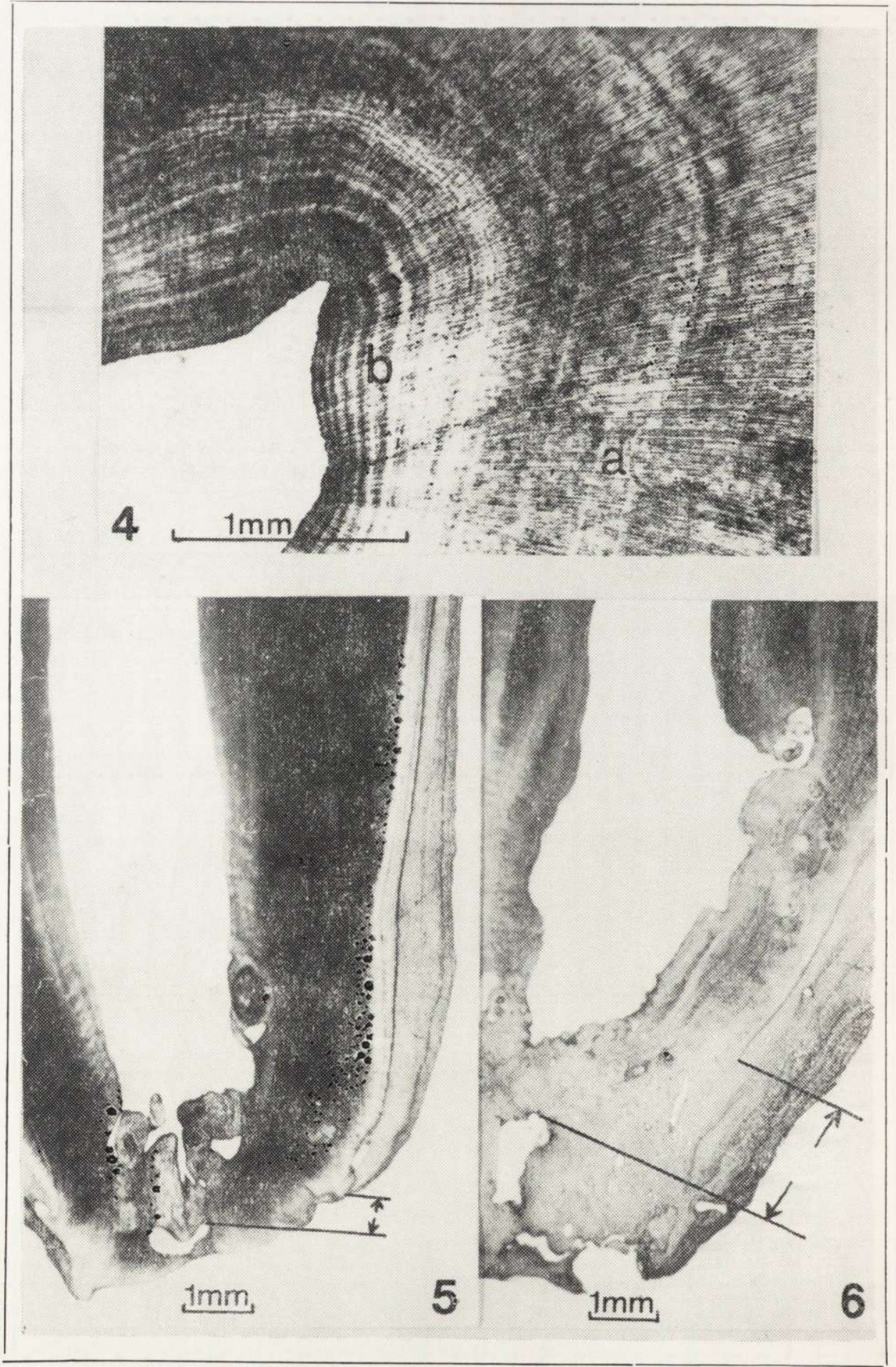

G. A. Klevezal \& Z. Pucek auctores phot. 